\title{
Adventitious root culture for secondary metabolite production in medicinal plants: A Review
}

\author{
Endang Rahmat • Youngmin Kang
}

Received: 10 June 2019 / Revised: 31 July 2019 / Accepted: 1 August 2019

(C) Korean Society for Plant Biotechnology

\begin{abstract}
Medicinal plants are high-value natural resources that have been used as precautionary drugs by many people globally. The increasing global demand for bioactive compounds from medicinal plants has led to the overexploitation of many valuable species. One widely used approach to overcome this problem is the use of adventitious root cultures as a propagation strategy. This review examines the scientific research published globally on the application of adventitious root cultures for many medicinal plants. Adventitious roots generated under aseptic environments in suitable phytohormone-augmented medium exhibit high growth rates and production of important secondary metabolites. Parameters such as medium properties and composition, growth hormone type, and elicitation strategies for in vitro grown adventitious roots of medicinal plants, are the main topics discussed in this review. We also examine current developments in bioreactor system cultivation for plant bioactive compounds using adventitious root cultures, a technology with possible commercial applications, via several studies on adventitious root culture of medicinal plants in which bioreactor systems play a role. In conclusion, the development of adventitious root cultures for medicinal plants is highly useful because of their capability for vegetative propagation and germplasm preservation.
\end{abstract}

Keywords Adventitious root culture, bioreactor, medicinal plants, secondary metabolites

E. Rahmat $\cdot$ Y. Kang $(\bowtie)$

University of Science \& Technology (UST), Campus of Korea Institute of Oriental Medicine, Korean Convergence Medicine major, Daejeon 34054, Republic of Korea

E. Rahmat $\cdot$ Y. Kang $(\bowtie)$

Herbal Medicine Resources Research Center, Korea Institute of Oriental Medicine, 111 Geonjae-ro, Naju-si, Jeollanam-do, 58245, Republic of Korea

e-mail: ymkang@kiom.re.kr

\author{
Abbreviations \\ PGRs : Plant Growth Hormones \\ MJ : Methil Jasmonate \\ SA : Salisilic Acid \\ BTBB : Baloon-Type Bubble Bioreactor \\ BCB : Bubble Column Bioreactor \\ TIS : Temporary Immersion System \\ IAA : Indole-3-Acetic Acid \\ IBA : Indole-3-Butyric Acid \\ NAA : 1-Naphthaleneacetic Acid \\ NOA : Naphthoxyacetic acid \\ 2,4-D : 2,4-Dichlorophenoxyacetic Acid \\ PAA : Phenylacetic Acid
}

\section{Introduction}

Medicinal plants are widely used globally as sources of raw materials in the pharmaceutical industry. Highly important bioactive compounds called plant secondary metabolites are intensively harvested from medicinal plants to improve human health and standard of life. The World Health Organization (WHO) has announced that approximately 80\% of humans worldwide utilize medicinal plant materials for primary health therapy (Raskin et al. 2002). However, human activities affect natural conservation and cause much damage. The development of modern cities, severe air pollution generated by vehicles, reduction of productive land because of housing developments, and substantial exploitation of natural resources have increased the difficulties in medicinal herb cultivation. In other words, the medicinal activity and efficacy of bioactive compounds derived from medicinal plants could be weakened by environmental disturbances and physiological damage, particularly by factors preventing their stable production (Beppu et al. 2004). In addition, current medicinal plants that are grown naturally, differ from their previous 
state because of increased contamination with pesticides, herbicides, fungicides, and heavy metals from industrial waste. This contamination is harmful to human health and reduces the quality of the herbs. Thus, the natural production of medicinal plants cannot meet increasing market needs. Furthermore, because of the intricate structure and configuration of plant secondary metabolites, artificial chemical synthesis has generally been found to be unsuitable in terms of cost. Therefore, obtaining sufficient medicinal herbal ingredients in the right manner has become a highpriority endeavor for the advancement of the global pharmaceutical industry (Gaosheng and Jingming 2012).

The primary metabolism of plants plays the important role of the synthesis of biologically active compounds called secondary metabolites. These products are not extensively involved in plant growth and development but are needed for specific functions such as conferring protection against environmental anomalies and stresses, as well as in plant defense against pathogens and herbivores. Owing to their ability and efficacy against pathogens, secondary metabolites are widely used as pharmaceuticals. Furthermore, these bioactive compounds are also utilized as food additives and agrochemical aromatics, emphasizing their importance for human life (Oksman-Caldentey et al 2004). There are three major groups of secondary metabolites: alkaloids (nitrogen and sulfur containing compounds), terpenoids, and phenolics. Normally, secondary metabolite production relies considerably on the developmental process and the physiological state of the plant, and yields are often very low (less than $1 \%$ in dry weight) (Rao et al., 2002; Thakur et al., 2013). Therefore, the development of alternative and highly creative strategies for overall plant cultivation is a very important social and economic challenge, especially for the high-output production of biologically essential bioactive compounds. For this reason, biotechnological approaches in plant cell, tissue, and organ culture have intensively been studied over the past several decades, as a prospective technology for the cultivation and production of pharmacologically beneficial plant bioactive compounds (Rao and Ravishankar 2002).

One approach that has been widely used for medicinal plant cultivation and production of highly valued compounds is micropropagation using in vitro culture. In 1934, White proposed the theory of totipotency for the first time. Then, in $1952 \sim 1953$, Steward verified the theory using carrot cells cultivated in aseptic liquid media to induce and obtain the whole plant. Thereafter, cell, tissue, and organ culture has evolved as a highly prospective technology for the cultivation and production of useful secondary metabolites derived from plants. In particular, their rapid ability to sprout and special capability for producing many secondary plant metabolites has led to the wide use of organ culture techniques such as adventitious root culture for medicinal plants (Murthy et al. 2008). Adventitious root cultures show a higher constancy in the production of highly active compounds with more rapid growth than that of cell culture (Sivakumar, 2006). In addition, bioreactor system cultivation for plant bioactive compounds using adventitious root cultures has emerged as a technology with possible commercial applications (Paek et al. 2009).

In the following highlight, the development of adventitious root culture techniques is presented and the current progress and innovation in secondary metabolites production from medicinal plants using different treatments of adventitious root cultures is reviewed and discussed.

\section{Formation of Adventitious Roots in Plants}

Plant roots have been demonstrated to be a plentiful resource of highly valued secondary metabolites that can be advantageous to human health (Bais et al. 2001). Adventitious roots are plant roots that arise from any organ other than the root itself, and form either during normal development or in response to environmental stresses, such as wounding, flooding, and mineral deficiency. They grow both underground and aerially and generally develop from leaves, stem nodes, and internodes. Adventitious roots serve many important roles for the plant and help the plant to survive even in environmentally adverse conditions.

Adventitious root formation has a complex molecular process involving numerous endogenous and exogenous physiological factors (Sorin et al. 2005). According to Zhang et al. (2017a), the formation stages of adventitious root can be divided into four steps: the root pre-emergence phase that includes molecular and biochemical process alterations occurring before any cytological occurrence until the emergence of primordial roots, the early phase of root development, the massive root growth phase, and the final phase of root configuration (Fig. 1). The process of induction and differentiation in the physiological stages of rooting can be triggered by changes in endogenous auxin concentrations and external addition of specific auxins (Praveen et al. 2009).

During the adventitious root formation, there are many changes in the endogenous subtances level. This is mainly related to the regulation of hormone levels which might play a role in it. In this case, auxin and ethylene primarily 


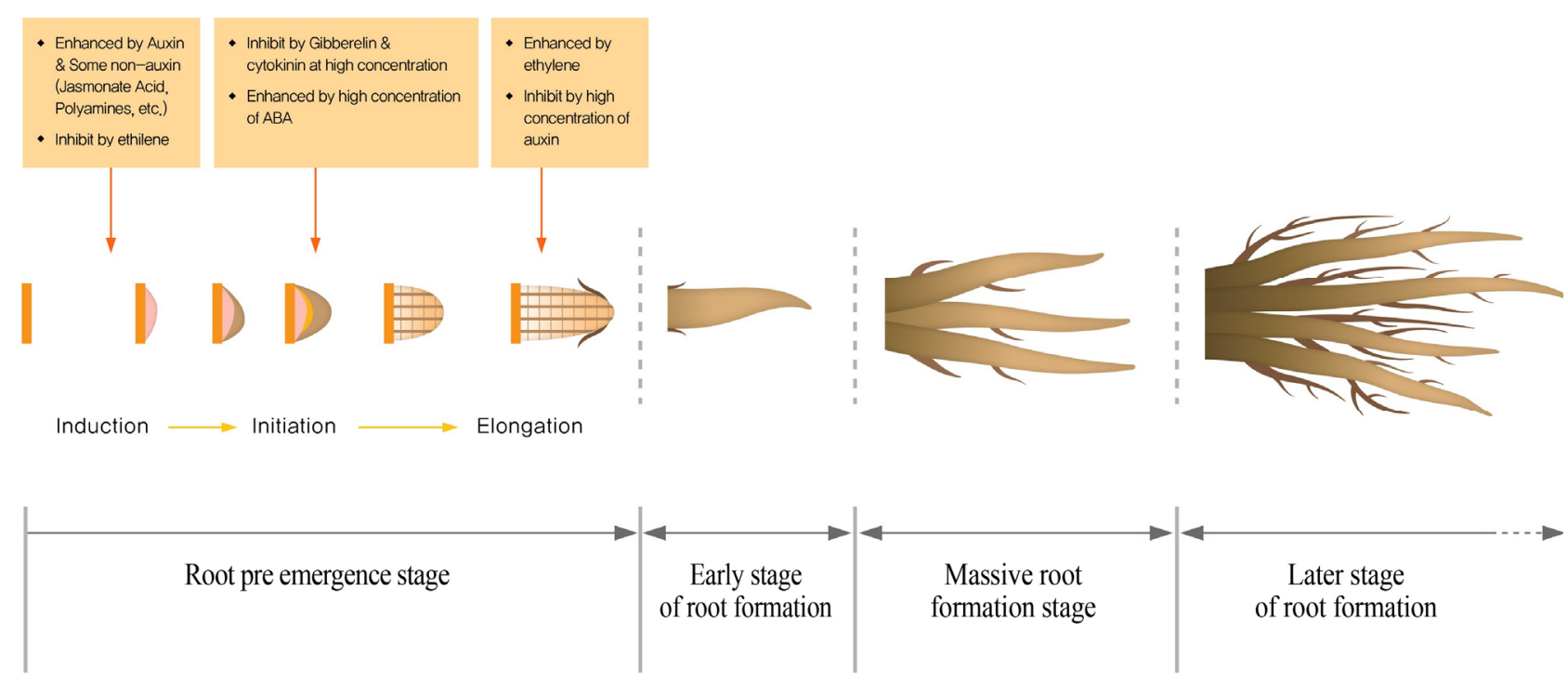

Fig. 1 Developmental phases on the organogenesis of adventitious root formation. There are four steps of adventitious root formation and proliferation. First is the root pre-emergence stage which includes dedifferentiation (induction), formation of root initials (initiation), development of an organized root primordia, and emergence of root primordia (elongation). In this first process, some PGRs such as auxin, cytokinin, ABA, and ethylene play a critical role in the adventitious root formation. The subsequent process is the early phase of root formation, massive root growth, and final phase of root development

act as activators, while cytokinin and ethylene play more roles as inhibitors (Pop et al. 2011). These hormones can help or inhibit the adventitious root formation process based on their concentration. For example, in the elongation process during the root pre-emergence phase (Fig. 1), too high auxin concentration actually inhibits the elongation process. Meanwhile, ethylene can be a counterweight that can trigger an elongation process. This occurs because the relationship between auxin and ethylene is one of the factors that can promote the formation of adventitious root (Pan et al. 2002). Gene expression for adventitious root induction in plants is fundamentally affected by a complex of microRNAs that have a significant regulatory role in controlling auxin response factors. Hormonal controls take place after new root establishment using auxins at low concentrations. A small amount of auxin is still needed for preserving and supporting root meristem, and cytokinins are required to trigger the differentiation of root tissue.

Actually, the mechanism of the adventitious root formation process is a very complicated process. Although the role of auxin in the formation of adventitious root is well known, some of the molecular processes that occur (particularly adventitious root formation-genes) are still unknown, therefore this mechanism represents an open for research area.

\section{Adventitious Root Culture Privilege}

Adventitious root formation is one of the key steps of in vitro propagation and is used for the cultivation and production of many plant crops, including medicinal plants. Recent advances in propagation techniques have resulted in the production of high amounts of biologically active compounds, such as phenols, terpenoids, and alkaloids using plant cell, tissue, as well as organs cultures (Gantet et al. 1998). Due to their rapid growth and stable metabolite productivity, adventitious root cultures are considered the most promising method for biomass production (Carvalho and Curtis 1998). Root cultures frequently show better biosynthetic ability than plant cell suspension cultures, which have low yields of secondary metabolites (Kevers et al. 1999). For instance, adventitious roots of important medicinal plants raised by micropropagation display increased biomass proliferation, accumulation potential, and bioactive compounds production. Hence, in vitro culture of adventitious roots has the potential to be developed as a strategy for large-scale bioactive compound production. Moreover, plant roots are the main raw materials that contribute to herbal drug preparations, accounting for about $60 \%$ of herbal medicinal plants applied for ethno-medicine needs. Therefore, adventitious root culture establishment is highly useful because of its capability for micropropagation and germplasm preservation (Sudha and Seeni 2001).

Adventitious roots show better growth rates and constant production of secondary metabolites when induced under an aseptic artificial environment in the optimal phytohormoneaugmented medium (Hahn et al. 2003). These roots generate high amounts of alkaloids, terpenoids, and phenols in their 
cell and tissue spaces and show high stability and growth rates, which can be easily produced in a suitable hormonesupplemented medium with a low quantity of inoculum (Sivakumar et al. 2006).

In some plant species, hairy root culture techniques using Agrobacterium transformation have been developed to produce secondary metabolite compounds from the roots of in vitro grown plants. Although hairy root cultures have high potential, some opine-like substrates that are dangerous to mammalian cells are usually produced as byproducts of the hairy root system (Choi et al. 2000). In addition, the purification cost of opine-like substrates is very high, which makes extraction from hairy root cultures very inefficient. Compared to hairy root cultures, adventitious roots do not need genetic modification, and extraction is relatively efficient because no opine-like substrates are produced. Hence, adventitious root culture techniques can be easily used instead of hairy root techniques because they are simpler and safer (Gaosheng and Jingming 2012).

Adventitious root cultures can be induced from field grown explants, in vitro grown explants, or from calluses. The types and combination of Plant Growth Regulators (PGRs) used play important roles in adventitious root culture formation. Lately, combinations of handling in cultivation processes such as elicitor supplementation, medium condition optimization, adjustment of precursor feeding, and bioreactor application are being studied for the generation of high-yield secondary metabolites. The development of adventitious root cultures by applying machine-driven bioreactor technology for all kinds of pharmacologically beneficial plants is important for the cultivation and production in huge quantities of plant-derived biologically active compounds to be used in various types of human healthcare and cosmetic products.

A list of pharmacologically valuable medicinal herbs where adventitious roots have been developed using various treatments and improvements for efficient and effective production of highly useful bioactive compounds has been compiled in Table 1 .

\section{Media Properties and Culture Condition Effects}

Optimal growth and morphogenesis of tissues may vary among different plants according to their nutritional requirements. For this reason, there are many factors influencing the optimal conditions for adventitious root culture of medicinal plants. These factors include the type and strength of the media used, the category, concentration, and characteristics of carbon source supplied, $\mathrm{pH}$ adjustment, and inoculum density. Various culture media are widely used for secondary metabolite studies to optimize nutritional requirements for the induction and proliferation of plant cells, tissues, and organs (Park et al. 2004). Diverse categories of media have significantly different effects on the growth and development of in vitro grown adventitious roots. Furthermore, various media properties such as media type, media salt strength, sucrose composition, and $\mathrm{pH}$ have been applied and broadly studied in terms of organ cultures, particularly in the adventitious root cultivation of herbal plants.

Different types of culture media have various effects on induction and proliferation of adventitious root culture of medicinal plants. It has been reported, MS media was very suitable for the induction and proliferation of the adventitious root culture of Boesenbergia rotunda, Vernonia amygdalina, Camellia sinensis, and Echinacea purpurea (Yusuf et al. 2018; Khalafalla et al. 2009; Kim et al. 2013; $\mathrm{Wu}$ et al. 2007). Of course, the optimal conditions were achieved with varying concentrations of MS media, such as full MS medium for adventitious root culture of Boesenbergia rotunda, and Vernonia amygdalina, while for Camellia sinensis and Echinacea purpurea optimal conditions were achieved with $1 / 2$ MS medium. Meanwhile, induction and proliferation of adventitious roots of Aloe vera could be optimized using B5 media compared to MS and SH media tested in this plant (Lee et al. 2011; 2013). From the various cases mentioned above, it can be noted that the most suitable type of culture media for establishment and growth of adventitious roots in medicinal plants are strongly influenced by the species of the medicinal plant itself.

In addition to choice of media used, the concentration of carbon sources needed for adventitious roots formation also varies for each species of medicinal plants. This happens because the ability of each plant species to absorb and process carbon source metabolism varies between one another. For example, $50 \mathrm{~g} / \mathrm{L}$ sucrose concentration was very suitable for adventitious root culture of Boesenbergia rotunda (Yusuf et al. 2018) and Eurycoma longifolia (Hussein et al. 2012), while $30 \mathrm{~g} / \mathrm{L}$ sucrose concentration had been successfully applied for adventitious root culture of Camellia sinensis (Kim et al. 2013). In adventitious root culture of Eurycoma longifolia, treatment with $50 \mathrm{~g} / \mathrm{L}$ sucrose generated around 3.2 adventitious roots per explant, this was better than other sucrose concentrations tested (Hussein et al. 2012). This shows that the appropriate sucrose concentration can trigger the formation of optimal adventitious root biomass. 
Table 1 List of medicinal plant species wherein adventitious roots have been developed through the exposure of various treatments and optimization strategies

\begin{tabular}{|c|c|c|c|c|c|c|}
\hline No. & Plant Species & $\begin{array}{l}\text { Secondary } \\
\text { Metabolites }\end{array}$ & $\begin{array}{l}\text { Optimized Conditions } \\
\text { (Media \& PGRs) }\end{array}$ & $\begin{array}{c}\text { Applied } \\
\text { Bioreactor } \\
\text { Types }\end{array}$ & $\begin{array}{l}\text { Bioreactor } \\
\text { Optimization } \\
\text { Strategies }\end{array}$ & References \\
\hline 1 & Aloe vera & $\begin{array}{c}\text { Aloe-emodin \& } \\
\text { Chrysophanol }\end{array}$ & $\begin{array}{c}\mathrm{B} 5+0.5 \mathrm{mg} / \mathrm{L} \\
\mathrm{NAA}+0.2 \mathrm{mg} / \mathrm{L} \mathrm{BA}\end{array}$ & - & - & Lee et al. 2011; 2013 \\
\hline 2 & $\begin{array}{l}\text { Andrographis } \\
\text { paniculata }\end{array}$ & Andrographolide & $\mathrm{MS}+2.7 \mu \mathrm{M}$ NAA & - & - & Praveen et al. 2009 \\
\hline 3 & $\begin{array}{l}\text { Boesenbergia } \\
\text { rotunda }\end{array}$ & Pinostrobin & $\mathrm{MS}+0.5 \mathrm{mg} / \mathrm{L} \mathrm{NAA}$ & - & - & $\begin{array}{l}\text { Azhar et al. 2018; } \\
\text { Yusuf et al. 2018 }\end{array}$ \\
\hline 4 & Camellia sinensis & Catechin \& Caffeine & $1 / 2 \mathrm{MS}$ & - & - & Kim et al. 2013 \\
\hline 5 & Centella asiatica & Asiaticoside & $\mathrm{MS}+7 \mathrm{mg} / \mathrm{L}$ IBA & - & - & Ling et al. 2009 \\
\hline 6 & $\begin{array}{l}\text { Chlorophytum } \\
\text { borivilianum }\end{array}$ & $\begin{array}{l}\text { Stigmasterol \& } \\
\text { Hecogenin }\end{array}$ & $\mathrm{MS}+3 \mathrm{mg} / \mathrm{L} \mathrm{IBA}$ & - & - & $\begin{array}{l}\text { Bathoju and Giri } \\
2012\end{array}$ \\
\hline 7 & Costus igneus & Resinoid & $\mathrm{MS}+0.5 \mathrm{mg} / \mathrm{L}$ IBA & - & - & Nagarajan et al. 2011 \\
\hline 8 & $\begin{array}{l}\text { Couroupita } \\
\text { guianensis }\end{array}$ & $\begin{array}{l}\text { Eugenol \& } \\
\text { Farnesol }\end{array}$ & $1 / 2 \mathrm{MS}+2 \mathrm{mg} / \mathrm{L} \mathrm{IBA}$ & - & - & $\begin{array}{l}\text { Manokari and } \\
\text { Shekhawa } 2016\end{array}$ \\
\hline 9 & $\begin{array}{l}\text { Echinacea } \\
\text { angustifolia }\end{array}$ & Flavonoid & $1 / 2 \mathrm{MS}+2 \mathrm{mg} / \mathrm{L} \mathrm{IBA}$ & - & - & Wu et al. 2006 \\
\hline 10 & Echinacea purpurea & $\begin{array}{c}\text { Caffeic acid } \\
\text { derivates }\end{array}$ & $1 / 2 \mathrm{MS}+1 \mathrm{mg} / \mathrm{L} \mathrm{IBA}$ & ВТВB & $\begin{array}{l}\text { - Media } \\
\text { replenishment: } \\
0.5 \mathrm{MS} \\
\text { - Aeration rate: } 0.1 \\
\text { vvm }\end{array}$ & Wu et al. 2007 \\
\hline 11 & Eurycoma longifolia & Quassinoid & $\mathrm{MS}+3 \mathrm{mg} / \mathrm{L}$ NAA & - & - & Hussein et al. 2012 \\
\hline 12 & Fagonia indica & $\begin{array}{l}\text { Apigenin, Gallic } \\
\text { acid, Rutin }\end{array}$ & $\mathrm{MS}+1 \mathrm{mg} / \mathrm{L}$ NAA & - & - & Khan et al. 2017 \\
\hline 13 & Gynura procumbens & $\begin{array}{l}\text { Kaempfrerol \& } \\
\text { Myricetin }\end{array}$ & $\begin{array}{c}\mathrm{MS}+3 \mathrm{mg} / \mathrm{L} \\
\mathrm{NAA}+1 \mathrm{mg} / \mathrm{L} \text { IBA }\end{array}$ & $\begin{array}{l}\text { BTBB \& } \\
\text { TIS } \\
\text { Bioreactor }\end{array}$ & $\begin{array}{l}\text { A. BTBB } \\
\text { - Aeration rate: } 0.2 \\
\text { vvm } \\
\text { B. TIS Bioreactor } \\
\text { - Immersion } \\
\text { frequency: } 15 \\
\text { min each } 12 \mathrm{~h} \\
\text { - Sucrose } \\
\text { concentration: } 5 \%\end{array}$ & Faizah et al. 2018 \\
\hline 14 & $\begin{array}{l}\text { Hypericum } \\
\text { perforatum }\end{array}$ & $\begin{array}{l}\text { Hypericin, } \\
\text { Quercetin, } \\
\text { Hyperoside }\end{array}$ & $\mathrm{MS}+1 \mathrm{mg} / \mathrm{L} \mathrm{IBA}$ & BTBB & $\begin{array}{l}\text { - Inoculum density: } \\
6 \mathrm{~g} / \mathrm{L} \mathrm{FW} \\
\text { - Sucrose } \\
\text { concentration: } 3 \% \\
\text { - Aeration volume: } \\
0.1 \mathrm{vvm}\end{array}$ & Cui et al. 2010 \\
\hline 15 & Labisia pumila & $\begin{array}{l}\text { Flavonoids \& } \\
\text { Phenolics }\end{array}$ & $\mathrm{MS}+5 \mathrm{mg} / \mathrm{L}$ IBA & - & - & Hasan et al. 2014 \\
\hline 16 & Luffa acutangula & Luffin & $\begin{array}{c}\mathrm{MS}+1 \mathrm{mg} / \mathrm{L} \\
\mathrm{IBA}+1 \mathrm{mg} / \mathrm{L} \text { NAA }\end{array}$ & - & - & $\begin{array}{l}\text { Umamaheswari et al. } \\
2014\end{array}$ \\
\hline 17 & Mondia whitei & $\begin{array}{l}\text { 2-hydroxy-4-methoxy } \\
\text { benzaldehyde }\end{array}$ & $\mathrm{MS}+2.5 \mu \mathrm{M}$ IAA & - & - & Baskaran et al. 2016 \\
\hline 18 & Morinda citrifolia & $\begin{array}{c}\text { Antrhaquinones, } \\
\text { Phenolic, Flavonoid }\end{array}$ & $\mathrm{MS}+5 \mathrm{mg} / \mathrm{L}$ IBA & - & - & Baque et al. 2012 \\
\hline 19 & $\begin{array}{l}\text { Orthosiphon } \\
\text { stamineus }\end{array}$ & Rosmarinic acid & $\mathrm{MS}+3 \mathrm{mg} / \mathrm{L}$ IAA & - & - & Ling et al. 2009 \\
\hline
\end{tabular}


Table 1 List of medicinal plant species wherein adventitious roots have been developed through the exposure of various treatments and optimization strategies (Continued)

\begin{tabular}{|c|c|c|c|c|c|c|}
\hline No. & Plant Species & $\begin{array}{l}\text { Secondary } \\
\text { Metabolites }\end{array}$ & $\begin{array}{l}\text { Optimized Conditions } \\
\text { (Media \& PGRs) }\end{array}$ & $\begin{array}{l}\text { Applied } \\
\text { Bioreactor } \\
\text { Types }\end{array}$ & $\begin{array}{c}\text { Bioreactor } \\
\text { Optimization } \\
\text { Strategies }\end{array}$ & References \\
\hline 20 & Panax ginseng & Ginsenoside & $\mathrm{MS}+25 \mu \mathrm{M}$ IBA & ВТВB & $\begin{array}{l}\text { - Co-culture system } \\
\text { - Co-culture } \\
\text { Inoculum ratio } \\
4: 1\end{array}$ & Wu et al. 2008 \\
\hline 21 & Panax quinquefolium & Ginsenoside & $\begin{array}{c}\mathrm{MS}+3 \mathrm{mg} / \mathrm{L} \\
\mathrm{IBA}+1 \mathrm{mg} / \mathrm{L} \text { NAA }\end{array}$ & - & - & Wang et al. 2016 \\
\hline 22 & $\begin{array}{l}\text { Perovskia } \\
\text { abrotanoides }\end{array}$ & Tanshinone & $\mathrm{MS}+2 \mathrm{mg} / \mathrm{L} \mathrm{NAA}$ & - & - & Zaker et al. 2015 \\
\hline 23 & $\begin{array}{l}\text { Podophyllum } \\
\text { hexandrum }\end{array}$ & Podophyllotoxin & $\mathrm{MS}+1.5 \mathrm{mg} / \mathrm{L} \mathrm{IBA}$ & - & - & Rajesh et al. 2012 \\
\hline 24 & $\begin{array}{l}\text { Polygonum } \\
\text { multiforum }\end{array}$ & $\begin{array}{c}\text { Antrhaquinones, } \\
\text { Phenolic, Flavonoid }\end{array}$ & $\mathrm{MS}+9.4 \mu \mathrm{M} \mathrm{IBA}$ & BTBB & $\begin{array}{l}\text { - Culture period: } 4 \\
\text { weeks } \\
\text { - Inoculum density: } \\
5 \mathrm{~g} / \mathrm{L} \\
\text { - Dissolved } \\
\text { oxygen: } 0.1 \mathrm{vvm}\end{array}$ & Ho et al. 2017, 2018 \\
\hline 25 & Prunella vulgaris & Prunellin & $\mathrm{MS}+0.5 \mathrm{mg} / \mathrm{L} \mathrm{NAA}$ & - & - & Fazal et al. 2014 \\
\hline 26 & $\begin{array}{l}\text { Psammosilene } \\
\text { tunicoides }\end{array}$ & $\begin{array}{l}\text { Triterpenoid } \\
\text { Saponin }\end{array}$ & $\begin{array}{c}\mathrm{B} 5+0.05 \mathrm{mg} / \mathrm{L} \\
\mathrm{IBA}+0.1 \mathrm{mg} / \mathrm{L} \mathrm{NAA}\end{array}$ & - & - & Zhang et al. $2017 \mathrm{~b}$ \\
\hline 27 & Psoralea coryfolia & Psoralen & $\mathrm{MS}+3 \mu \mathrm{M}$ IBA & - & - & $\begin{array}{l}\text { Baskaran and } \\
\text { Jayabalan N } 2009\end{array}$ \\
\hline 28 & Raphanus sativus & Anthocyanin & $\mathrm{MS}+0.5 \mathrm{mg} / \mathrm{L}$ IBA & - & - & Betsui et al. 2004 \\
\hline 39 & Rubia tinctorum & $\begin{array}{l}\text { Antrhaquinones, } \\
\text { Phenolic }\end{array}$ & MS & - & - & Bicer et al. 2017 \\
\hline 30 & Rumex crispus & $\begin{array}{l}\text { Antrhaquinones, } \\
\text { Flavonoids }\end{array}$ & $\mathrm{MS}+5 \mu \mathrm{M}$ NAA & - & - & Mahdieh et al. 2015 \\
\hline 31 & Scopolia parviflora & Scopolamine & $\mathrm{B} 5+0.1 \mathrm{mg} / \mathrm{L} \mathrm{IBA}$ & $\begin{array}{l}\text { Bubble } \\
\text { Column } \\
\text { Bioreactor }\end{array}$ & $\begin{array}{l}\text { - Inoculum density: } \\
3 \mathrm{~g} / \mathrm{L} \\
\text { - Aeration rates: } \\
0.4 \mathrm{vvm} \\
\text { - Culture period: } 3 \\
\text { weeks }\end{array}$ & $\begin{array}{l}\text { Kang et al. 2004; } \\
\text { Jung et al. 2003; } \\
\text { Min et al. } 2007\end{array}$ \\
\hline 32 & Silybum marianum & Silymarin & $\mathrm{MS}+2 \mathrm{mg} / \mathrm{L}$ IBA & - & - & Riasat et al. 2015 \\
\hline 33 & Talinum paniculatum & Saponin & $\mathrm{MS}+2 \mathrm{mg} / \mathrm{L}$ IBA & ВТВB & $\begin{array}{c}\mathrm{NaHCO}_{3} \\
\text { supplementation }\end{array}$ & Solim et al. 2017 \\
\hline 34 & Vernonia amigdala & $\begin{array}{l}\text { sesquiterpene } \\
\text { lactones }\end{array}$ & $1 / 2 \mathrm{MS}+2 \mathrm{mg} / \mathrm{L} \mathrm{IBA}$ & - & - & Khalafalla et al. 2009 \\
\hline 35 & Withania somnifora & Whitanolide & $\begin{array}{c}1 / 2 \mathrm{MS}+0.5 \mathrm{mg} / \mathrm{L} \\
\mathrm{IBA}+0.25 \mathrm{mg} / \mathrm{L} \mathrm{IAA}\end{array}$ & - & - & Thilip et al. 2015 \\
\hline
\end{tabular}

In addition to the increament of adventitious root biomass, suitable sucrose concentrations also affect the increased production of secondary metabolites. As with Boesenbergia rotunda's adventitious root culture, the highest yield of pinostrobin content $(3.54 \mathrm{mg} / \mathrm{g})$ was achieved with $50 \mathrm{~g} / \mathrm{L}$ sucrose concentrations compared to other concentrations (Joseph et al. 2018).
A study on the effect of sucrose concentrations for optimizing the adventitious root culture of medicinal plants was also undertaken for Gynura procumbens (Saiman et al. 2012), Hypericum perporatum (Cui et al. 2010), and Psammosilene tunicoide (Zhang et al. 2017b). To optimize the growth conditions for adventitious root culture for Gynura procumbens, the strength of MS medium $(1 / 2,1,3 / 2$, and 
$2)$, the concentration of carbon source $(1,2,3,5$, 7, and $10 \% \mathrm{w} / \mathrm{v})$, initial $\mathrm{pH}$ adjustment $(5.0,5.5,5.75,6.0$, and $6.5)$, and dark versus light conditions were studied. The results showed that $2 \%$ sucrose was the most suitable for root culture growth (Saiman et al. 2012). The differences in carbon source concentrations, especially sucrose $(0,1,3$, $5,7$, or $9 \%$ in $w / v)$, also had significant effects on the adventitious root culture of Hypericum perporatum. Based on the study conducted by Cui et al. (2010), greater concentrations of sucrose $(5,7$, and $9 \%)$ prevented biomass production due to the influence of osmotic pressure which was very high, but in contrast, the optimum biomass accumulation was actually produced using medium supplemented with $3 \%(\mathrm{~b} / \mathrm{v})$ concentration of sucrose. Furthermore, in a study on adventitious root cultures of Psammosilene tunicoide, the culture conditions were designed as follows: the concentrations of sucrose were $0,20,30,40$, and $50 \mathrm{~g} / \mathrm{L}$; photoperiods were $0,8,10$, and $12 \mathrm{~h} / \mathrm{d}$; initial $\mathrm{pH}$ was 5.0 , 5.5, 5.8, 6.0, and 6.5; and the light intensity was $2000 \mathrm{Lx}$. Experiments using this design revealed the best culture properties for bioactive compound production to be the 30 $\mathrm{g} / \mathrm{L}$ concentration of sucrose, $10 \mathrm{~h} / \mathrm{d}$ photoperiod, and initial pH 5.8 (Zhang et al. 2017b).

\section{Role of Plant Growth Regulators (PGRs)}

The formation of adventitious roots mainly depends on anatomical status. Induction and differentiation pathways in the rooting process can be stimulated by artificially providing certain auxin hormones (Praveen et al. 2009). In addition, physiological stages of rooting can be affected by changes in endogenous auxin concentrations (Fig. 1). Auxin is a plant hormone that has several functions in different cellular processes, especially in controlling the growth, development and proliferation of a plant cell. This hormone comes from the amino acid tryptophan. The most widely distributed auxin and has been widely used, namely indoleacetic acid (IAA) and indole-3-butyric acid (IBA). After successfully studied the original structure of auxin, the scientist then succeeded in making artificial auxin called synthetic growth regulators. Two types of auxin synthetic which play a role in the rooting process, for example 1-Naphthaleneacetic acid (NAA) and 2,4-Dichlorophenoxyacetic acid (2,4-D).

Many studies have also shown that the efficacy of diverse auxins for the establishment and propagation of in vitro grown adventitious roots varies by the family and species of the plant (Baskaran and Jayabalan 2009). In addition, the type of auxin also greatly influences the process of induction and proliferation of the adventitious root culture. Based on various reports presented in table 1, IBA is the most suitable auxin for induction and development of adventitious root culture of medicinal plants. IBA, compared to other types of auxin, is a hormone that is very suitable for the adventitious root culture of Centella asiatica, Costus igneus, Couroupita guianensis Aubl., Echinacea angustifolia, Labisia pumila, Podophyllum hexandrum, Psoralea coryfolia, Silyabum marianum, and Vernonia amygdala (Ling et al. 2009; Nagarajan et al. 2011; Manokari and Shekhawat 2016; Jang et al. 2012; Hasan et al. 2014; Rajesh et al. 2012; Baskaran and Jayabalan 2009; Riasat et al. 2015; Khalafalla et al. 2009; Khalafalla et al. 2009). One thing to note, IBA influences the formation and development of adventitious root culture in medicinal plants in various different concentrations. In adventitious root culture of Centella asiatica, $7 \mathrm{mg} / \mathrm{L}$ IBA was found to be the optimal auxin for adventitious root formation compared to those of tested NAA and IAA at different levels of concentration (Ling et al. 2009). In Costus igneus, IBA at a concentration of $0.5 \mathrm{mg} / \mathrm{L}$ was more effective for producing adventitious roots of Costus igneus than were other treatments using IAA at all concentrations tested (Nagarajan et al. 2011). Meanwhile, $2 \mathrm{mg} / \mathrm{L}$ IBA was determined to be of optimum concentration for Couroupita guianensis Aubl. (Manokari and Shekhawat 2016), Echinacea angustifolia (Jang et al. 2012), Silyabum marianum (Riasat et al. 2015), and Vernonia amygdala (Khalafalla et al. 2009) compared to IAA, NAA, and event NOA (Naphthoxyacetic acid) at various concentrations. Moreover, the effects of various auxins at different concentrations have also been evaluated for Labisia pumila by Hasan et al. (2014), which results in $5 \mathrm{mg} / \mathrm{L}$ IBA as the most suitable condition for adventitious root induction of this medicinal plant. Based on these results, it is important to note that the dosage of auxin is one of a key factor in the induction of adventitious rooting.

Besides IBA, NAA also has a significant influence on induction and proliferation of adventitious root culture of medicinal plants. It has been reported that NAA is the best auxin hormone for establishment of adventurous root culture of Andrographis paniculata, Boesenbergia rotunda, Eurycoma longifolia, Fagonia indica, Mondia whitei, and Rumex crispus (Praveen et al. 2009; Azhar et al. 2018; Hussein et al. 2012; Khan et al. 2017; Baskaran et al. 2016; Mahdieh et al. 2015). In the study of adventitious roots culture of medicinal plant Andrographis paniculata, NAA at $2.7 \mu \mathrm{M}$ in concentration having a higher biomass accu- 
mulation (fresh and dry weight) and andrographolide content within four weeks of culture compared to those of IAA and IBA (Praveen et al. 2009). For adventitious root culture of Rumex crispus, $5 \mu \mathrm{M}$ of NAA is a very suitable concentration for inducing and proliferating adventitious root culture of this plant (Mahdieh et al. 2015). Meanwhile, a greater concentration, $10 \mu \mathrm{M}$ NAA, is the optimum condition for adventitious root culture of Mondia whitei (Baskaran et al. 2016). Moreover, NAA with a concentration of 0.5 , 1 , and $3 \mathrm{mg} / \mathrm{L}$ is reported to be suitable for the induction and proliferation of adventitious root culture of Boesenbergia rotunda (Azhar et al. 2018), Eurycoma longifolia (Hussein et al. 2012), and Fagonia indica (Khan et al. 2017), respectively. In adventitious root culture of Fagonia indica, among all concentrations of auxins tested, the root formation activity from callus explants was significantly decreased when the concentration of any auxin was increased (Khan et al. 2017).

Compared to IBA and NAA, the naturally occurring auxin hormone IAA apparently has the lowest efficacy in promoting adventitious root culture of medicinal plant. IAA only superior when its applied for the establishment of adventititous root culture of Orthosiphon stamineus. This study with adventitious root culture of Orthosiphon stamineus revealed that $3 \mathrm{mg} / \mathrm{L}$ IAA was the best auxin to promote rooting in leaf explants. Although IBA and NAA also induced root formation, their rooting ability was lower than that of IAA (Ling et al. 2009). This proves that in the case of formation and proliferation of adventitious roots of medicinal plant, synthetic auxin seems to have a more significant effect compared to naturally occurring auxin such as IAA. In addition, several studies have also reported that IBA and NAA can be combined at the same time to produce optimal growth conditions for adventitious root culture of medicinal plants. For example, a combination of IBA at $1 \mathrm{mg} / \mathrm{L}$ and NAA at $1 \mathrm{mg} / \mathrm{L}$ is very suitable for Luffa acutangula (L.) Roxb. (Umamaheswari et al. 2014) and a combination of $0.05 \mathrm{mg} / \mathrm{L} \mathrm{IBA}+0.1 \mathrm{mg} / \mathrm{L} \mathrm{NAA}$ is the optimal condition for Psammosilene tunicoides (Zhang et al. 2017b).

\section{Effects of Biotic and Abiotic Elicitation}

Stress levels are an important factor for the growth and development of medicinal plants, especially for secondary metabolite accumulation and therapeutic activity. Plant stress responses can be actively stimulated using elicitation techniques to generate the desired metabolic process response in the biosynthetic pathway. Stress factors that raise or enhance the biosynthesis of a specific secondary metabolite compound when applied in small quantities are called elicitors. The specific compounds influenced by elicitors have a significant role in the adaptation of plants to environmental pressure. Elicitation is considered the most practical and feasible strategy among several biotechnological approaches that have been studied and employed for productivity improvement of appealing biologically active compounds from cells, organs, and whole plant components. In general, there are two groups of elicitors, namely, biotic and abiotic elicitors. Biotic elicitors are substances of biological origin such as fungi, bacteria, yeast, and polysaccharides derived from the plant cell walls (e.g., cellulose, pectin, and chitin). However, abiotic elicitors include substances of non-biological origin and are grouped as hormonal, physical, and chemical factors. The explanations below summarize the studies of in vitro grown adventitious roots of medicinal plants in which elicitation strategies played a role (Table 2).

\section{Abiotic Elicitors}

Some abiotic elicitors such as $\mathrm{MJ}, \mathrm{SA}, \mathrm{CuSO}_{4}, \mathrm{AgNO}_{3}$, sorbitol, caffeic acid, oxalic acid, phenyl acetic acid (PAA), and ethephon have been applied to improve the biosynthesis and accumulation of secondary metabolites produced by adventitious root culture of medicinal plants. Almost all the studies that have been carried out, aim to compare the various types and concentrations of elicitor in order to obtain the most optimal elicitation strategy to increase the production of bioactive compounds. Among the various types of abiotic elicitors mentioned above, MJ was the most suitable type of abiotic elicitor for most adventitious root culture of medicinal plants such as Fagonia indica, Hypericum perforatum, Panax ginseng, Panax quinquefolium, Polygonum multiforum, and Scopolia parviflora (Khan et al. 2017; Cui et al. 2010; Wu et al. 2008; Wang et al. 2016; Ho et al. 2018; Kang et al. 2004). MJ can increase the synthesis of secondary metabolites in adventitious root culture through signal transduction which will accelerate the enzyme catalysis process, thus bioactive compounds such as alkaloids, flavonoids, terpenoids, and polyphenols will be formed (Zhao et al. 2005). Treatment with MJ as a proven elicitor can activate key differentially expressed genes (DEGs) in biosynthetic pathways from the secondary metabolite of interest. For example, feeding with MJ on adventitious root culture of Panax quinquefolium activated UDP-xylose synthases (c52571_g3) which are thought to play a role in increasing ginsenoside biosynthesis by 
Table 2 List of medicinal plant species wherein elicitation strategies have been applied into adventitious root cultures

\begin{tabular}{|c|c|c|c|c|c|}
\hline No. & Species & Secondary Metabolites & Applied Elicitors & $\begin{array}{c}\text { Highest Increment of Metabolite } \\
\text { Yield }\end{array}$ & References \\
\hline 1 & Aloe vera & $\begin{array}{l}\text { Aloe-emodin \& } \\
\text { Chrysophanol }\end{array}$ & SA, MJ, Ethephon & $\begin{array}{l}\text { - Aloe-emodin Increased } \\
\text { approximately } 10 \text {-fold by SA } \\
\text { - Chrysophanol increased } 5-13 \\
\text { fold by SA }\end{array}$ & Lee et al. 2013 \\
\hline 2 & Fagonia indica & Apigenin, Rutin & MJ \& PAA & $\begin{array}{l}\text { - Apigenin increased } 1.6 \text {-fold by } \\
\text { MJ } \\
\text { - Gallic acid increased } 5.3 \text {-fold by } \\
\text { MJ }\end{array}$ & Khan et al. 2017 \\
\hline 3 & $\begin{array}{l}\text { Gynura } \\
\text { procumbens }\end{array}$ & $\begin{array}{l}\text { Kaempfrerol \& } \\
\text { Quercetin }\end{array}$ & $\begin{array}{l}\text { Saccharomiyces } \\
\text { sereviciae, } \mathrm{C}_{\mathrm{u}} \mathrm{SO}_{4}\end{array}$ & $\begin{array}{l}\text { - Kaempferol increased } 13.3 \text {-fold } \\
\text { by } \mathrm{C}_{\mathrm{u}} \mathrm{SO}_{4} \\
\text { - Querectin increased 1.9-fold by } \\
\text { S. sereviciae }\end{array}$ & Faizah et al. 2018 \\
\hline 4 & $\begin{array}{l}\text { Hypericum } \\
\text { perforatum }\end{array}$ & Phenols & $\begin{array}{l}\text { MJ, SA, Lactabumin } \\
\text { hydrolysate }\end{array}$ & $\begin{array}{l}\text { - Total Phenolic compounds } \\
\text { increased } 1.2 \text {-fold by MJ }\end{array}$ & Cui et al. 2010 \\
\hline 5 & $\begin{array}{l}\text { Morinda } \\
\text { citrifolia }\end{array}$ & $\begin{array}{l}\text { Antrhaquinones, } \\
\text { Phenolic, Flavonoid }\end{array}$ & Chitosan \& Pectin & $\begin{array}{l}\text { - Antrhaquinones increased } \\
1.4 \text {-fold by chitosan } \\
\text { - Phenolic increased } 1.08 \text {-fold by } \\
\text { chitosan } \\
\text { - Flavonoid increased } 1.12 \text {-fold by } \\
\text { chitosan }\end{array}$ & Baque et al. 2012 \\
\hline 6 & Panax ginseng & Ginsenoside & MJ & - Ginsenoside increased 8-fold & Wu et al. 2008 \\
\hline 7 & $\begin{array}{l}\text { Panax } \\
\text { quinquefolium }\end{array}$ & Ginsenoside & MJ & - Ginsenoside increased 5.24-fold & Wang et al. 2016 \\
\hline 8 & $\begin{array}{l}\text { Perovskia } \\
\text { abrotanoides }\end{array}$ & Tanshinone & $\begin{array}{l}\mathrm{MJ}, \mathrm{AgNO} \\
\text { Yeast Extract }\end{array}$ & $\begin{array}{l}\text { - Cryptotanshinone increased } \\
\text { 3.63-fold by Yeast Extract } \\
\text { - Tanshinone IIA increased } \\
\text { 1.91-fold by } \mathrm{AgNO}_{3}\end{array}$ & Zaker et al. 2015 \\
\hline 9 & $\begin{array}{l}\text { Polygonum } \\
\text { multiforum }\end{array}$ & Phenolic & $\begin{array}{l}\text { MJ, SA, Yeast } \\
\text { Extract, Chitosan }\end{array}$ & $\begin{array}{l}\text { - Total phenolic increased } \\
\text { 1.42-fold by MJ }\end{array}$ & Ho et al. 2018 \\
\hline 10 & $\begin{array}{l}\text { Psammosilene } \\
\text { tunicoides }\end{array}$ & Triterpenoid Saponin & Oxalic acid & $\begin{array}{l}\text { - Total saponin increased } 1.65 \\
\text { fold }\end{array}$ & Zhang et al. $2017 \mathrm{~b}$ \\
\hline 11 & Rubia tinctorum & Antrhaquinones & MJ \& Caffeic acid & $\begin{array}{l}\text { - Total Antrhaquinones increased } \\
\text { 2-fold by combination of MJ \& } \\
\text { Caffeic acid }\end{array}$ & Bicer et al. 2017 \\
\hline 12 & $\begin{array}{l}\text { Scopolia } \\
\text { parviflora }\end{array}$ & Scopolamine & MJ, SA, Bacteria & $\begin{array}{l}\text { - Scopolamine increased } \\
\text { approximately } 1.4 \text {-fold by MJ } \\
\text { - Hyosiamine increased } \\
\text { approximately } 2.2 \text {-fold by MJ }\end{array}$ & $\begin{array}{l}\text { Kang et al. 2004; } \\
\text { Jung et al. } 2003\end{array}$ \\
\hline
\end{tabular}

5.24-fold compared to controls (Wang et al. 2016). When a key gene that plays a role in biosynthesis of secondary metabolite of interest is activated by the presence of MJ, at that time the production of these active compounds will increase. For more instances, treatment with MJ increased biosynthesis of apigenin by 1.6-fold on Fagonia indica, phenolic compound by 1.2-fold on Hypericum perforatum, ginsenoside by 8 -fold on Panax ginseng, phenolic compounds by 1.2-fold on Polygonum multiforum, scopolamine 1.4-fold and hyosiamine 2.2-fold on Scopolia parviflora (Khan et al. 2017; Cui et al. 2010; Wu et al. 2008; Ho et al. 2018; Kang et al. 2004).
Besides MJ, SA also showed good efficacy in increasing secondary metabolite accumulation in adventitious root culture of medicinal plants. SA could increase the production of Aloe-emodin by 10-fold and chrysophanol by 13-fold in Aloe vera, better than MJ and ethephon tested in this plant. Just like MJ, SA is one of the plant hormones that can stimulate the expression of the biosynthetic pathway genes of secondary metabolites. Moreover, these two hormones can activate the defense mechanism in plants. This can lead to an adverse effect on the growth of adventitious roots biomass along with the increasing concentrations of MJ and SA given, as happened in Hypericum 
perforatum (Cui et al. 2010) and Scopolia parviflora (Kang et al. 2004).

In addition to $\mathrm{MJ}$ and $\mathrm{SA}$, compounds containing heavy metals such as $\mathrm{CuSO}_{4}$ and $\mathrm{AgNO}_{4}$ also showed good ability as an abiotic elicitor for adventitious root culture of medicinal plants. Heavy metals can induce changes in plant metabolic processes and affect the production of proteins, sugars, photosynthetic pigments, and secondary metabolites (Thakur et al. 2019). It has been reported that $\mathrm{CuSO}_{4}$ could increase kaempferol production in adventitious root culture of Gynura procumbens by 13.3-fold compared to control (Faizah et al. 2018). While $\mathrm{AgNO}_{3}$ could increase the production of tanshinone IIA by 1.91-fold when applied to adventitious root culture of Perovskia abrotanoides, better than treatment with MJ, sorbitol, and yeast extract (Zaker et al. 2015).

Ethephon, Caffeic acid, and Oxalic acid are also abiotic elicitors which can be considered to be applied in order to increase bioactive compounds from adventitious root culture of medicinal plants. Although its efficacy was still below MJ and SA, these compounds could still increase the accumulation of secondary metabolites (Lee et al. 2013; Bicer et al. 2017; Zhang et al. 2017b). In addition, to produce optimal effects, a combination of several abiotic elicitors can be considered. For example, a combination of MJ and caffeic acid could increase the production of antraquinones in 2-fold adventitious root culture of Rubia tinctorum, better than treatment alone with $\mathrm{MJ}$ or caffecic acid (Bicer et al. 2017).

\section{Biotic Elicitors}

Biotic elicitors are elicitors that come from living organisms. Biotic elicitors can pair with receptors and act by activating or deactivating enzymes or ion channels (Thakur et al. 2019). Some biotic elicitors have been shown to increase the production of secondary metabolites in adventitious root culture of medicinal plants, namely yeast extract $(S$. cerevisiae), chitosan, pectin, and several species of bacteria. Yeast extract enhanced querectin accumulation by 1.9-fold in Gynura procumbens (Faizah et al. 2018) and cryptotanshinone production by 3.63-fold in Perovskia abrotanoides (Zaker et al. 2015). Yeast can stimulate plant defense response which, as a result, is directly related to the biosynthesis of secondary metabolites.

The effect of chitosan and pectin on the increase in secondary metabolite production has been demonstrated in the adventitious root culture of Morinda citrifolia (Baque et al. 2012). In that study, $0.2 \mathrm{mg} / \mathrm{L}$ chitosan was better than pectin by increasing the production of anthraquinones, flavonoids, and phenolics by 1.4-fold, 1.08-fold, and 1.12-fold, respectively. Pectin and chitosan are carbohydrates whose efficacy as biotic elicitor has been widely studied by scientists. In addition, some species of bacteria could also increase the accumulation and production of secondary metabolites of root culture of medicinal plants (Jung et al. 2003). Treatment of adventitious root culture of medicinal plant with bacteria, particularly the plant growth promoting rhizobacteria (PGPR), would enhance the plant's defense response to producing such bioactive compounds. In addition, PGPR also encourages biosynthesis of endogenous jasmonic acid which then acts as a tranducer for elicitor signaling pathways, which can increase the production of secondary metabolites.

\section{Scale up in Bioreactors}

The rapid advancement in the field of biotechnology research has facilitated the production of secondary metabolites from medicinal plants using cell, tissue, and organ cultures. To meet the increasing needs of the global market for drug compounds, it is important to produce these compounds in large quantities. In this context, adoption of a laboratory-scale production system for commercial scale production is a challenge. Researchers have applied bioreactor technology to scale up the production of bioactive compounds from plants. The bioreactor system is far more profitable compared to growing plants conventionally in nature because the entire process occurs in a bioreactor that can be controlled to produce high-quality yields in large quantities. Therefore, to successfully cultivate cell, tissue, and organ cultures of plants, as well as to produce bioactive compounds in the bioreactor, several engineering parameters such as aeration, fluid mixing, carbon dioxide evolution rate, temperature, shear sensitivity, $\mathrm{pH}$, and dissolved oxygen must be considered (Fig. 2).

More specifically, bioreactor technology has been applied to produce secondary metabolites from medicinal plants. Manuhara et al. (2017) compared the biomass production of adventitious roots of Gynura procumbens in different liquid cultures (shake flask, temporary immersion bioreactor, and balloon-type bubble bioreactor). Low oxygen and submerged conditions in the medium induce several problems in liquid culture such as asphyxia (less oxygen) and hyperhydricity. A temporary immersion system bioreactor and balloon-type bubble bioreactor can be applied to overcome these problems. Hyperhyd-ricity and asphyxia can be eliminated by adjusting the immersion times of Temporary Immersion System (TIS) bioreactors (Etienne 


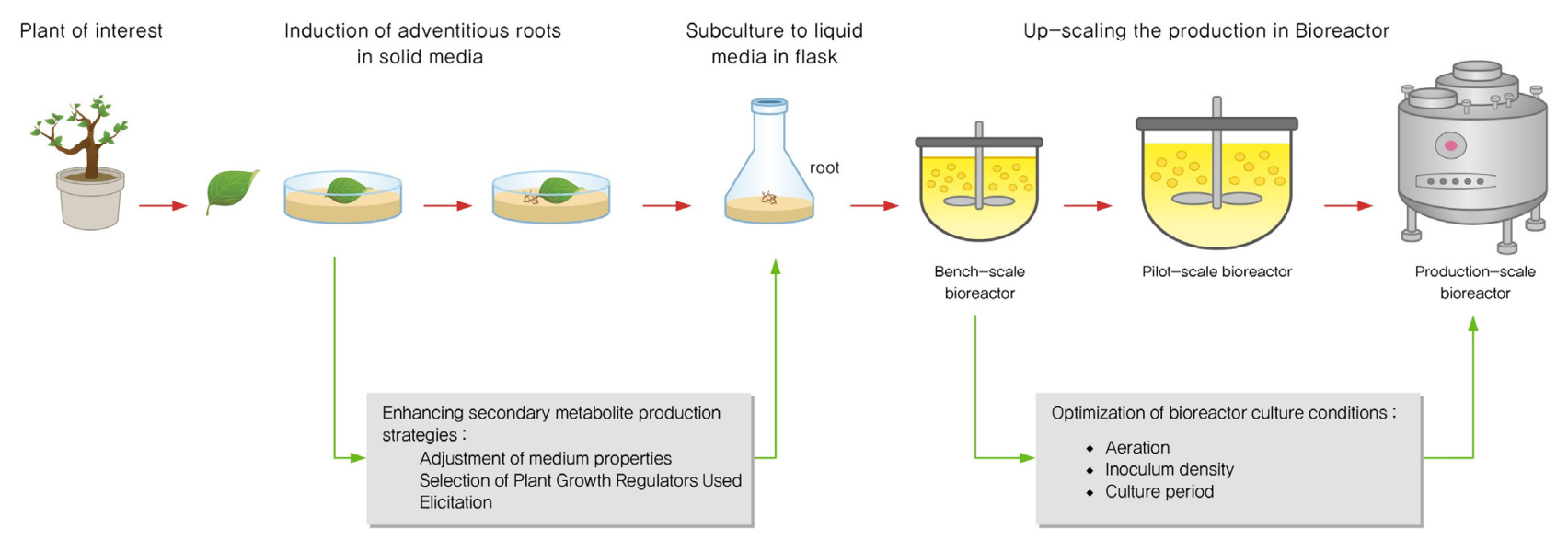

Fig. 2 Scale-up production strategy for adventitious root culture production using the bioreactor. Adventitious roots induced from explants in solid medium are subcultured into liquid medium on the flask until eventually transferred into the bioreactor system from small-scale to production-scale. Some parameters such as medium properties, PGRs, and elicitation must be evaluated in to achieve optimized condition for the culture. To enhance the yield production, some engineering parameters on the bioreactor should be optimized as well such as aeration, inoculum density, culture period, fluid mixing, shear sensitivity, etc.

and Berthouly 2002). Furthermore, aeration systems are used in balloon-type bubbles, which can stimulate the growth rates of the culture. Bubbles in the Balloon-Type Bubble Bioreactor (BTBB) reduce shear forces; therefore, this kind of bioreactor is suitable for culturing plant organs. The results of this study showed that the highest biomass production (fresh weight) was found in the balloon-type bubble bioreactor (13.1-fold higher than initial explant) followed by that in the temporary immersion system bioreactor (5.12-fold higher than initial explant), and shake flask (3.9-fold higher than initial explant), respectively (Manuhara et al. 2017).

Large-scale culture using the bioreactor system was also adopted for adventitious root culture of Hypericum perporatum L. In vitro grown adventitious roots were raised using leaf explants in MS solid medium and were then moved into shake flasks of $250 \mathrm{~mL}$ in size (Cui et al., 2014). Parameters including aeration volume, inoculum density, ammonium/nitrate ratio, sucrose concentration, and MS salt strength were evaluated to determine the best conditions for the adventitious root culture of this plant. Subsequently, adventitious roots were maintained on the medium with the same properties in a 3 L BTBB. Finally, an airlift bioreactor sized $500 \mathrm{~L}$ was employed to further culture the adventitious roots. The results revealed that the pattern of adventitious root growth in the larger bioreactors was similar to that in smaller bioreactors (Cui et al. 2014).

Scale-up cultivation of Polygonum multiforum adventitious root cultures was established for phenolic compound production. Various chemicals and physical parameters, such as inoculum density and culture periods were optimized in a 3-L bioreactor. This optimized condition was then applied for large production systems (4 and $20 \mathrm{~L}$ ) and a pilot production system $(500 \mathrm{~L})$. The results revealed that the root biomass outcome was lower in the $500 \mathrm{~L} \mathrm{BTBB}$, but the accumulation of secondary metabolites remained the same. Moreover, enzyme activity with high antioxidant was found in the 500-L bioreactor culture system, which probably indicates the relatively high oxidative stress produced at this culture capacity. Overall, this work led to the possibility of establishing adventitious root cultures of Polygonum multiforum at the commercial scale (Ho et al. 2017).

Several years ago, a study on bioreactor application in medicinal plants was also performed for adventitious root culture of Scopolia parviflora. This study evaluated several parameters that play a significant role in the optimization of an adventitious root culture in Bubble Column Bioreactor (BCB) such as inoculum size and effect of elicitors. The results indicated that inoculum density and air flow in BCB influenced the accumulation of hyoscyamine and scopolamine content. Furthermore, scopolamine and hyoscyamine content were relatively enhanced using the bioreactor system in contrasted to flask grown cultures, whereas the biomass continually increased with the culture time (Min et al. 2007).

Other medicinal plant species for which bioreactor technology was studied are listed in Table 1 . These works on scale up production systems using bioreactors for adventitious root cultures of medicinal plants can pave the way for future advancement of biotechnological industries. These can fulfill the increasing requirement for natural drug raw materials, particularly in the pharmaceutical and cosmetics industries. 


\section{Future Perspectives}

Implementation of adventitious root cultures in basic and applied research of numerous medicinal plant species has been increasing rapidly. This is because application of biotechnology, particularly in vitro culture techniques for mass propagation of medicinal plant species and for the production of secondary metabolites has become industrially worthwhile.

Successful propagation of adventitious root cultures for the fabrication of medicinally useful secondary metabolites demands the selection of a suitable bioreactor. Preference specifications are determined according to a number of elements intrinsic to certain plant cell or tissue cultures and are affected by the ultimate objectives of the study. Due to the particular characteristics of plant adventitious root cultures, bioreactor systems may remarkably differ from those applied for culturing animal cells or microorganisms. Further, the distinction between one adventitious root culture to another can be massive; it is thus clear that the optimal bioreactor systems for plant adventitious root cultures differ based on the properties of the plant species. For the mass production of valuable secondary metabolites, the process needs to be optimized and scaled up to an economically justifiable size, which is normally done by increasing the size of the bioreactor or by parallelizing the bioreactor. Furthermore, the effective use of artificial neural networks (ANN) based on prior approximations of culture conditions can improve the entire production process of secondary metabolite synthesis through adventitious root culture (Prakash et al. 2010). Eventually, several strategies such as integrated bioreactor technology, metabolic and bioreactor engineering, genetic transformation, two-phase and two-stage culture systems, and precursor feeding can be further applied to enhance the synthesis of medicinal secondary metabolites (Baque et al. 2012).

In future developments in plant-derived secondary metabolite production, the combination of mining, accessing, and conservation of plant genetic resources and optimization strategies in the production process itself could be the prime concerns. The availability of more cost-efficient, high throughput "omics" technologies (genomics, transcriptomics, proteomics, metagenomics), along with bioinformatics, has provided new opportunities and tools to obtain deeper insights into the mechanisms and interactions of pivotal genes for the synthesis of secondary metabolites of interest. Application of "omics" to plant tissue culture will certainly help to unravel complex developmental processes such as organogenesis and somatic embryogenesis, which will probably enable to improve the efficiency of regeneration protocols for recalcitrant species. Additionally, metabolomics applied to tissue culture will facilitate the extraction and characterization of complex mixtures of natural plant products of industrial interest. These technologies have been applied for adventitious root culture of Panax quinquefolium (Wang et al. 2013) and Aloe vera (Lee et al. 2013). Therefore, this approach can be used further to study secondary metabolite production from adventitious root cultures of other medicinal plants.

\section{Conclusion}

The rapid advancement in biotechnology has rendered adventitious root cultures as one of the main choices for secondary metabolite production from medicinal plants. Many studies have been conducted to produce active compounds from medicinal plants using adventitious root culture techniques. Different improvements and process optimizations have been examined to enhance the secondary metabolites production in adventitious root cultures. However, both physical and chemical optimization is essential to produce abundant and high-quality yields. These optimization processes include proper culture conditions, the suitability of the type of media used, elicitation, and other influential parameters. In addition, scale-up production using bioreactors is also important to meet the market demands for natural drugs to cure various diseases. However, the scale-up process still needs to be optimized before it is applied for industrial production.

\section{Acknowledgments}

This work was supported by Development of Foundational Techniques for the Domestic Production of Herbal Medicines (K18405), Applicational Development of Standardized Herbal Resources (KSN1911420), Korea Institute of Oriental Medicine through the Ministry of Science and ICT, Republic of Korea.

\section{References}

Azhar SZA, Ghani KA, Yusuf NA (2018) In vitro induction of adventitious root from shoot bud of Boesenbergia rotunda (Zingiberaceae): effect of plant growth regulators. Sci Int 30(1):147-151

Bais HP, Loyala-Vargas VM, Flores HE, Vivanco JM (2001) Root-specific metabolism: the biology and biochemistry of underground organs. In Vitro Cell Dev Biol Plant 37:730-41 
Baskaran P, Jayabalan N (2009) Psoralen production in hairy roots and adventitious roots cultures of Psoralea coryfolia. Biotechnol Lett 31:1073-1077

Baskaran P, Kumari A, Ncube B, Staden JV (2016) Acetylcholinesterase-inhibition and antibacterial activity of Mondia whitei adventitious roots and ex vitro-grown somatic embryogenicbiomass. Front Pharmacol 7:335

Bathoju G, Giri A (2012) Production of medicinally important secondary metabolites (stigmasterol and hecogenin) from root cultures of Chlorophytum borivilianum (Safed musli). Recent Res Sci Tech 4(5): 45-48

Baque MA, Shiragi MHK, Lee EJ, Paek KY (2012) Elicitor effect of chitosan and pectin on the biosynthesis of anthraquinones, phenolics and flavonoids in adventitious root suspension cultures of Morinda citrifolia (L.). AJCS 6(9):1349-1355

Beppu H, Kawai K, Shimpo K, Chihara T, Tamai I, Ida C, Ueda M, Kuzuya H (2004) Studies on the components of Aloe arborescens from Japan-monthly variation and differences due to part and position of the leaf. Biochem Syst Ecol 32:783-795

Betsui F, Nishikawa NT, Shimomura K (2004) Anthocyanin production in adventitious root cultures of Raphanus sativus L. cv. Peking Koushin. Plant Biotechnol 21(5):387-391

Bicer PO, Demirci T, Asci OA, Baydar NG (2017) Effects of methyl jasmonate and caffeic acid applications on secondary metabolite production in madder (Rubia tinctorum) root cultures. Indian J Pharm Edu 51:508-512

Carvalho E, Curtis WR (1998) Characterization of fluid-flow resistance in root cultures with a convective flow tubular bioreactor. Biotech Bioeng 60:375-384

Choi SM, Son SH, Yun SR, Kwon OW, Seon JH, Paek KY (2000) Pilot-scale culture of adventitious roots of ginseng in a bioreactor system. Plant Cell Tiss Organ 62:187-93

Cui XH, Murthy HN, Wu CH, Paek KY (2010) Sucrose-induced osmotic stress affects biomass, metabolite, and antioxidant levels in root suspension cultures of Hypericum perforatum $\mathrm{L}$. Plant Cell Tiss Organ 103:7-14

Cui XH, Murthy HN, Paek, KY (2014) Production of adventitious root biomass and bioactive compounds from Hypericum perforatum L. through large scale bioreactor cultures. In: Paek KY, Murthy HN, Zhong JJ (Ed) Production of biomass and bioactive compounds using bioreactor technology. Springer, Dordrecht, pp 251-284

Etienne H, Berthouly M, (2002) Temporary immersion system in plant micropropagation. Plant Cell Tiss Organ 69(3):215-231

Faizah H, Tanjung M, Purnobasuki H, Manuhara YS (2018) Biomass and flavonoid production of Gynura procumbens (L.). Merr adventitious root culture in Baloon-type BubbleBioreactor (BTBB) influenced by elicitation. Asian J Plant Sci 17:107-119

Fazal H, Abbasi BH, Ahmad N (2014) Optimization of adventitious root culture for production of biomass and secondary metabolites in Prunella vulgaris L. Appl Biochem Biotechnol 174:2086-2095

Gantet P, Imbanlt N, Thiersault M, Doireau M (1998) Necessary of a functional octadecanoic pathway for indole alkaloid synthesis by Catharanthus roseus cell suspensions cultured in an auxinstarved medium. Plant Cell Physiol 39:220-225

Gaosheng H, Jingming J (2012) Production of useful secondary metabolites through regulation of biosynthetic pathway in cell and tissue suspension culture of medicinal plants. Recent Advances in Plant in vitro Culture. London, UK. pp 11:197-210

Hahn EJ, Kim YS, Yu KW, Jeong CS, Paek KY (2003) Adventitious root cultures of Panax ginseng C.A. Meyer and ginsenoside production through large-scale bioreactor system. J Plant Biotech 5:1-6

Hasan NA, Hussein S, Ibrahim R (2014) Plant growth regulator effect on adventitious roots induction of Labisia pumila. Mal J Fun Appl Sci 10:49-52

Ho TT, Lee KJ, Lee JD, Bhushan S, Paek KY, Park SY (2017) Adventitious root culture of Polygonum multiflorum for phenolic compounds and its pilot-scale production in 500 L-tank. Plant Cell Tiss Organ 130(1):167-181

Ho TT, Lee JD, Jee CS, Paek KY, Park SY (2018) Improvement of biosynthesis and accumulation of bioactive compounds by elicitation in adventitious root culture of Polygonum multiforum. Appl Microbiol Biotechnol 102:199-209

Hussein S, Ling APK, NG TH, Ibrahim R, Paek KY (2012) Adventitious roots induction of recalcitrant tropical woody plant, Eurycoma longifolia. Rom Biotech Lett 17(1):7026-7035

Jang YS, Cui HY, Lee EJ, Kim HW, Paek KY (2012) Auxin effects on production of adventitious roots and secondary metabolites in Echinacea angustifolia. Korean J Med Crop Sci 20(6):479-486

Jung HY, Kang SM, Kang YM, Kang MJ, Yun DJ et al. (2003) Enhanced production of scopolamine by bacterial elicitors in adventitious hairy root cultures of Scopolia parviflora. Enzyme Microb Technol 33:987-990

Kang SM, Jung HY, Kang YM, Yun DJ, Bahk JD et al. (2004) Effects of methyl jasmonate and salicylic acid on the production of tropane alkaloids and the expression of PMT and $\mathrm{H} 6 \mathrm{H}$ in adventitious root cultures of Scopolia parviflora. Plant Sci 166:745-751

Kevers C, Jacques Ph, Thonart Ph, Gaspar Th (1999) In vitro Root Culture of Panax ginseng and Panax quinquefolium. Plant Growth Regul 27:173-178

Khalafalla MM, Daffalla HM, El-Shemy HA, Abdellatef E (2009) Establishment of in vitro fast-growing normal root culture of Vernonia amygdalina - a potent African medicinal plant. Afric J Biotechnol 8(21):5952-5957

Khan T, Abbasi BH, Khan MA, Azeem M (2017) Production of biomass and useful compounds through elicitation in adventitious root cultures of Fagonia indica. Ind Crop Prod 108:451-457

Kim YD, Kim HG, Sim SJ, Kim JC, Min JY et al. (2013) Effects of culture media on catechins and caffeine production in adventitious roots of tea tree (Camellia sinensis L.). J Agric Life Sci 47(1):11-20

Lee YS, Yang TJ, Park SU, Baek JH, Wu SQ, Lim KB (2011) 
Induction and proliferation of adventitious roots from Aloe vera leaf tissues for in vitro production of aloe-emodin. Plant Omics 4(4):190-194

Lee YS, Ju HK, KimYJ, Lim TG, Uddin MR, KimYB et al. (2013) Enhancement of anti-inflammatory activity of Aloe vera adventitious root extracts through the alteration of primary and secondary metabolites via salicylic acid elicitation. PLOS ONE 8(12): e82479. doi:10.1371/journal.pone.0082479

Ling APK, Chin MF, Hussein S (2009) adventitious Root Production of Centella asiatica in response to plant growth regulators and sucrose concentration. Medicinal Aromatic Plant Sci Biotechnol 3(1):36-41

Ling APK, Kok KM, Hussein S, Ong SL (2009) Effects of plant growth regulators on adventitious roots induction from different explants of Orthosiphon Stamineus. Am-Eurasian J Sustain Agric 3(3):493-501

Mahdieh M, Noori M, Hoseinkhani S (2015) Establishment of in vitro adventitious root cultures and analysis of flavonoids in Rumex crispus. Plant Tissue Cult Biotechnol 25(1):63-70

Manokari M, Shekhawat M (2016) Implications of auxins in induction of adventitious roots from leaf explants of cannon ball tree (Couroupita guianensis Aubl.). World Sci News 33:109-121

Manuhara YSW, Kusuma DY, Sari RLK, Kristanti AN (2013) Biomass production of Gynura procumbens adventitious roots in different type of liquid culture. Biosaintifika 3:523-529

Min JY, Jung HY, Kang SM, Kim YD, Kang YM, Park DJ et al. (2007) Production of tropane alkaloids by small-scale bubble column bioreactor cultures of Scopolia parviflora adventitious roots. Bioresour Technol 98:1748-1753

Murthy HN, Hahn EJ, Paek KY (2008) Adventitious roots and secondary metabolism. Chin J Biotechnol 24:711-716

Nagarajan A, Arivalagan U, Rajagru P (2011) In vitro root induction and studies on antibacterial activity of root extract of Costus igneus on clinically important human pathogens. J Microbiol Biotech Res 1(4): 67-76

Oksman-Caldentey KM, Inzé D (2004) Plant cell factories in the post-genomic era: new ways to produce designer secondary metabolites. Trends plant sci 9: 433-440

Paek KY, Murthy HN, Hahn EJ, Zhong JJ (2009) Large scale culture of ginseng adventitious roots for production of ginsenosides. Adv Biochem Eng Biotechnol 113:151-176

Pan R, Wang J, Tian X (2002) Influence of ethylene on adventitious root formation in mung bean hypocotyl cuttings. Plant Grow Regul 36(2):135-139

Park YG, Kim SJ, Kang YM et al (2004) Production of ginkgolides and bilobalide from optimized the Ginkgo biloba cell culture. Biotechnol Bioproc Eng 9: 41-46

Pop TI, Pamfil D, Bellini C (2011) Auxin Control in the Formation of Adventitious Roots. Not Bot Hort Agrobot Cluj 39(1): 307-316

Prakash O, Mehrotra S, Krishna A, Mishra BN (2010) A neural network approach for the prediction of in vitro culture parameters for maximum biomass yields in hairy root cultures. J Theor Biol 265:579-85
Praveen N, Manohar SH, Naik PM, Nayeem A, Jeong JH, Murthy $\mathrm{HN}$ (2009) Production of androghrapholide from adventitious root cultures of Andrographis paniculata. Curr Sci 96:5-10

Rajesh M, Jeyaraj M, Sivanandhan G, Subramanyam K, Dev GK, Ganapathi A (2012) Adventitious root culture in Podophyllum hexandrum Royle (syn. P. emodi Wall. ex Hook.f. \& Thomas) - An important medicinal plant. J Biotechnol Biomater 2:6

Rao SR, Ravishankar GA (2002) Plant cell cultures: chemical factories of secondary metabolites. Biotechnol adv 20:101-153

Raskin I, Ribnicky DM, Komarnytsky S, llic N, Poulev A et al (2002) Plants and human health in the twenty-first century. Trends Biotechnol 20:522-531

Riasat R, Riasat Z, Abbasi BH, Liu C, Khan MA (2015) Silybum marianum: adventitious roots induction along with free radical scavenging activity. J Plant Biol Res 4(1):12-21

Saiman MZ, Mustafa NR, Schulte AE, Verpoorte R, Choi YH (2012) Induction, characterization, and NMR-based metabolic profiling of adventitious root cultures from leaf explants of Gynura procumbens. Plant Cell Tiss Organ 109:465-475

Shabbir, A., Shahzad, M., Masci, P., Gobe, G.C., 2014. Protective activity of medicinal plants and their isolated compounds against the toxic effects from the venom of Naja (cobra) species. J Ethnopharmacol 157:222-227

Sivakumar G (2006) Bioreactor technology: a novel industrial tool for high-tech production of bioactive molecules and biopharmaceuticals from plant root. Biotechnol J 12:1419-1427

Solim MH, Kristanti AN, Manuhara YSW (2017) Influence of explant position on growth of Talinum paniculatum Gaertn. adventitious root in solid medium and enhance production biomass in balloon type bubble bioreactor. IOP Conf Ser: Earth and Environ Sci 58:12-23

Sorin C, Bussell JD, Camus I et al (2005) Auxin and light control of adventitious rooting in Arabidopsis required ARGONAUTE1. The Plant Cell 17:1343-1359

Sudha CG, Seeni S (2001) Establishment and analysis of fast-grown normal root culture of Decalepis arayalpathra, a rare endemic medicinal plant. Curr Sci 81:371-374

Thakur GS, Sharma R, Sanodiya BS, Baghel R, Thakur R, Singh $\mathrm{BN}$ et al (2013) In vitro induction of tuber formation for the synthesis of secondary metabolites in Chlorophytum borivilianum Sant. et Fernand. Afr J Biotechnolo12(20)

Thakur M, Bhattacharya S, Khosla PK, Puri S (2019) Improving production of plant secondary metabolites through biotic and abiotic elicitation. J Appl Res Med Aromat Plants 12:1-1

Thilip C, Raju CS, Arutharaju K, Aslam A, Shajahan A (2015) Establishment of adventitious root culture fom cell suspension of Whitania somnifora (L.) Dunal: an in vitro approach for production of whitanolides. Int J Pharm Bio Sci 6(1):1030-1037

Umamaheswari C, Ambethkar A, Margareth FS, Selvaraj N (2014) In vitro root culture from roots and leaf explants of $L u f f a$ Acutangula (L.) Roxb. IJIRSET 3:16886-16895

Wang J, Li J, Li J, Liu S, Wu X, Li J, Gao W (2016) Transcriptome profiling shows gene regulation patterns in ginsenoside pathway in response to methyl jasmonate in Panax Quinquefolium adventitious root. Sci Rep 6:37263 
Wiesman Z, Riov J, Epstein E (1988). Comparison of movement and metabolism of indole-3-acetic acid and indole-3-butyric acid in mung bean cuttings. Physiol Plant 74(3):556-560

Wu CH, Dewir YH, Hahn EJ, Paek KY (2006) Optimization of culturing conditions for the production of biomass and phenolics from adventitious root of Echinacea angustifolia. J Plant Biol 49(3):193-199

Wu CH, Murthy HN, Hahn EJ, Paek KY (2007) Improved production of caffeic acid derivatives in suspension cultures of Echinacea purpurea by medium replenishment strategy. Arch Pharm Res 30(8):945-949

Wu CH, Murthy HN, Hahn EJ, Paek KY (2008) Establishment of adventitious root co-culture of Ginseng and Echinacea for the production of secondary metabolites. Acta Physiol Plant 30:891-896

Yusuf NA, Rahim NSM, Azhar SZA, Ghani KA, Sommano S, Khalid N (2018) Adventitious root cultures of Boesenbergia rotunda as a source of Pinostrobin. Int Journal on Adv Sci Eng IT 8:377-383
Zaker A, Sykora C, Gossnitzer F, Abrishamchi C, Asili J, Mousavi $\mathrm{SH}$, Wawrosh C (2015) Effects of some elicitors on tanshinone production in adventitiousroot cultures of Perovskia abrotanoides Karel. Ind Crop Prod 67:97-102

Zhang W, Fan J, Tan Q, Zhao M, Zhou T, Cao F (2017a) The effects of exogenous hormones on rooting process and the activities of key enzymes of Malus hupehensis stem cuttings. PLOS ONE 12(2): e0172320. doi:10.1371/journal.pone.0172320

Zhang Z, Yu Z, Jin Z, Liu J, Li Y (2013) Liquid culture of adventitious roots is a potential alternative to field cultivation for Psammosilene tunicoides, a rare and endangered endemic medicinal plant. Adv J Food Sci Tech 5(2):127-131

Zhang Z, Zou D, Liu M, Cong M, Cheng N, Gao H, Wang S, Liu $\mathrm{Z}$, Li G (2017b) Induction of Psammosilene tunicoides adventitious roots and the accumulation of triterpenoid saponins as affected by culture conditions. Int J Agric Biol 19:1535-1540

Zhao J, Davis LC, Verpoorte L (2005) Elicitors signal transduction leading to production of plant secondary metabolites. Biotechnol Adv 23(4): 283-333 